\title{
Impacts of Improved Switchgrass and Big Bluestem Selections on Yield, Morphological Characteristics, and Biomass Quality
}

\author{
Erik Delaquis, ${ }^{1}$ Roger Samson, ${ }^{2}$ Philippe Seguin, ${ }^{1}$ Arif Mustafa, ${ }^{3}$ and Huguette Martel ${ }^{4}$ \\ ${ }^{1}$ Department of Plant Science, McGill University, Macdonald Campus, 21111 Lakeshore Road, Sainte-Anne-de-Bellevue, \\ QC, Canada H9X 3 V9 \\ ${ }^{2}$ REAP Canada, 21111 Lakeshore Road, Sainte-Anne-de-Bellevue, QC, Canada H9X 3V9 \\ ${ }^{3}$ Department of Animal Science, McGill University, Macdonald Campus, 21111 Lakeshore Road, Sainte-Anne-de-Bellevue, \\ QC, Canada H9X 3V9 \\ ${ }^{4} M A P A Q$, Direction Régionale de l'Estrie, Sherbrooke, QC, Canada J1N $2 A 5$ \\ Correspondence should be addressed to Philippe Seguin; philippe.seguin@mcgill.ca
}

Received 15 September 2014; Accepted 17 November 2014; Published 17 December 2014

Academic Editor: Qiquan Wang

Copyright (C) 2014 Erik Delaquis et al. This is an open access article distributed under the Creative Commons Attribution License, which permits unrestricted use, distribution, and reproduction in any medium, provided the original work is properly cited.

\begin{abstract}
Switchgrass (Panicum virgatum L.) and big bluestem (Andropogon gerardii V.) are promising warm-season grasses for biomass production. Understanding the morphological and quality-related traits of these grasses can guide breeders in developing strategies to improve yield and quality for bioindustrial applications. Elite selections were made in Southern Quebec from four promising varieties of switchgrass and one of big bluestem. Biomass yield, morphological characteristics, and selected quality traits were evaluated at two sites in 2011 and 2012. Significant variation was detected for all measured characteristics, with differences varying by site and year. In some cases the selection process modified characteristics including increasing height and reducing tiller mortality. Switchgrasses reached a similar tiller equilibrium density in both years of $690 \mathrm{~m}^{-2}$ and $379 \mathrm{~m}^{-2}$ at a productive and marginal site, respectively. Differences in yield were pronounced at the marginal site, with some advanced selections having a higher yield than their parent varieties. Switchgrass yields were generally greater than those of big bluestem. A delayed spring harvest date greatly reduced yield but reduced moisture content and slightly increased cellulose concentration. Big bluestem had a higher cellulose content than switchgrass, likely due to greater stem content.
\end{abstract}

\section{Introduction}

Switchgrass (Panicum virgatum L.) is a perennial $\mathrm{C}_{4}$ grass native to North America which has historically been used as a forage crop and for conservation plantings [1-3]. Recently interest has shifted towards the use of the crop in biomass energy and biofibre applications [4], with research indicating significant production potential in Eastern Canada [5]. Growing interest in this multipurpose crop has led to an increasing number of breeding and selection programmes and the release of new commercial switchgrass selections in the 1980s ("Trailblazer," "Forestburg," "Dacotah," and "KY1625"), 1990s ("Sunburst" and "Shawnee"), and 2000s ("High Tide," "Carthage," "BoMaster," "Performer," "Cimarron," and "Colony") [6-8]. Despite an increasing acreage dedicated to the production of this crop in Eastern Canada, these selections all represent the efforts of plant material improvement programs located in the Atlantic Coastal, Midwest, and Northern Great Plains regions of the United States. There has been little selection effort in situ in Eastern Canada or in the Northeastern United States.

Big bluestem (Andropogon gerardii Vitman) is the most dominant grass of the tallgrass prairie ecosystem and has been demonstrated to be another high yielding warm-season grass in the Eastern North American context [9, 10]. Fully established stands of big bluestem can approximate the yields of switchgrass stands of a similar maturity [10, 11]. Big bluestem is generally taller than upland switchgrass and native big bluestem ecovars have been found to contain $62 \%$ of the biomass in the stem component [12], compared with native switchgrass with $47 \%$ [13]. Big bluestem appears to have some biomass quality advantages over switchgrass for certain 
fibre applications as it generally has improved fibre strength properties [11] and higher cellulose contents due to its higher stem-to-leaf ratio [14]. In an assessment of 5 switchgrasses and 4 big bluestems at heading, it was found that there were no differences in cellulose contents between big bluestem and switchgrass stems and leaves; however, stems of both species had on average $11 \%$ higher cellulose contents than leaves [14]. Early-harvested big bluestem has also been identified to have improved digestibility for livestock due to its leafy composition prior to heading [15]. Big bluestem has been used for forming polycultures with switchgrass and other native grasses and forbs in mixed prairie systems. Mixtures have many demonstrated benefits including increased indigenous avian and arthropod diversity and species richness [16, 17] and once fully established can produce similar yields to switchgrass monocultures $[18,19]$.

Switchgrass production in Quebec currently covers about 1500 ha, with the acreage increasing up to $30 \%$ per year (Huguette Martel, unpublished data). The vast majority of this acreage is the variety "Cave-in-Rock," a collection made from a field in Cave-in-Rock, Illinois, in 1958 [20]. Previous experiences indicate that appropriate regional selections can significantly increase yield potential in a given environment [21], but despite this there are currently no commercial varieties available that have been developed specifically for agronomic applications for Eastern Canada or the Northeastern United States. There has also been no plant breeding effort conducted in these regions for big bluestem.

Previous studies with switchgrass and tall fescue confirmed the effectiveness of seedling-stage selection for developing selections with modified tiller number [22-24] and increased yield per tiller $[22,25]$. It has also been demonstrated that selection and breeding programmes have the capacity to alter fiber composition in switchgrass [26], an important characteristic for energy and fibre crops. Fiber content, including lignin and cellulose concentrations, has been demonstrated to be important parameters for multiple conversion technologies and thus important breeding targets for biomass crops [15].

The development of a spring harvest system for switchgrass is another potential avenue for improving biomass quality for energy and fibre applications. In biomass crops, the leaching of minerals from plant tissues throughout the winter has been shown to result in lower mineral concentrations [27, 28 ], while the loss of leaves may decrease the concentration of major ash components such as silicates and increase cellulose content [29]. Elevated levels of silica are generally considered undesirable for commercial combustion processes [30]. Spring harvesting also carries the added advantages of reducing labor demands during peak harvest time for commercial cash crops and drastically reducing moisture content at harvest which reduces or eliminates the need for drying [31] and is thus beneficial for baling and storage [27].

The goal of the present study was to compare the agronomic characteristics of several commercial varieties of upland switchgrass and big bluestem along with advanced selections made from these varieties to determine the effects on their performance and morphological characteristics in Southern Quebec. Several of these selections were also subjected to both spring and fall harvest to determine the effects of harvest date on yield, fiber, mineral, and energy concentrations of the harvested biomass.

\section{Material and Methods}

2.1. Plant Materials. Selection lines and parent material were supplied by REAP-Canada, based in Southern Quebec (Sainte-Anne-de-Bellevue, QC, Canada). The biomass breeding program is utilizing short breeding cycles incorporating selection at the seedling stage followed by recurrent restricted phenotypic selection (RRPS) in mature spaced-plant nurseries [32]. A total of 11 upland switchgrass selections and three big bluestem selections were evaluated. These included three switchgrass parent varieties and seven selections derived from these (Table 1). "Sandlover," a selection made by REAPCanada from "NU-94-2" [15], was also evaluated bringing the total switchgrass selections evaluated to eleven. In addition, two selections of big bluestem were also evaluated alongside their parent material "Prairie View Indiana germplasm".

The "Blue Jacket" and "Blue Jacket II" switchgrass selections were made from "Sunburst" switchgrass using RRPS [33]. The population of "Blue Jacket II" was selected for reduced tillering at the seedling stage, with 200 superior plants selected from a population of 1000 plants [22] followed by a RRPS selection made on mature plants. The "Blue Jacket Early" selection was derived from 50 plants which exhibited early spring growth in the year after establishment in a one ha seed field of "Blue Jacket" switchgrass in Valleyfield, Quebec. The plants were dug up in the spring of 2008 and replanted and seed was collected from the population in the fall of 2009.

"Cave-in-Rock II" was derived from a seed collection in the fall of 2006 from 30 superior plants in an eight-yearold switchgrass field in Valleyfield, Quebec. The population was subsequently selected for reduced tillering at the seedling stage were transplanted in the field [22]. At the mature plant stage, the population was selected using RRPS and seed derived from superior plants from a 200-spaced-plant nursery was collected in fall 2009. The "Cave-in-Rock Early" population was derived from seed collected in fall of 2009 from 30 early maturing switchgrass plants in a 10 -year-old field of "Cave-in-Rock" switchgrass in Valleyfield, Quebec.

The "Tecumseh" and "Tecumseh II" selections were made from "Summer” switchgrass using RRPS [33]. A greenhouse population of 1000 plants of "Tecumseh II" was selected for reduced tillering at the seedling stage [22]. At the mature plant stage, the population was selected using RRPS and seed derived from superior plants from the 200-spaced-plant nursery was collected in fall of 2009.

"Sandlover" was derived from 200 plants selected from a 1,000-spaced-plant nursery in Valleyfield, Quebec, using RRPS [33]. The original source population was Northern Upland "NU-942" obtained from Charles Taliaferro at the University of Oklahoma in 2006.

Finally, the selections "Prairie View Early" and "Prairie View II" were selected from an 800-spaced-plant nursery of Prairie View Indiana germplasm big bluestem originally transplanted in 2008 in Valleyfield, Quebec. 
TABLE 1: Origins of the commercial switchgrass and big bluestem varieties evaluated in the present study and the selections derived from them through a local selection programme in Southern Quebec.

\begin{tabular}{|c|c|c|c|c|}
\hline Variety/selection & Year of release & Site of origin & Latitude of origin $\left({ }^{\circ} \mathrm{N}\right)$ & References \\
\hline \multicolumn{5}{|l|}{ Switchgrass } \\
\hline Cave-in-Rock & 1958 & Cave-in-Rock, Illinois & 37 & Jefferson and McCaughey, 2012 [6] \\
\hline Cave-in-Rock II & N/A & Valleyfield, Quebec & & Present study \\
\hline Cave-in-Rock Early & N/A & Valleyfield, Quebec & & Present study \\
\hline Summer & 1953 & Nebraska City, Nebraska & 41 & Jefferson and McCaughey, 2012 [6] \\
\hline Tecumseh & N/A & Valleyfield, Quebec & & Present study \\
\hline Tecumseh II & N/A & Valleyfield, Quebec & & Present study \\
\hline Sunburst & 1998 & Union County, South Dakota & 43 & Jefferson and McCaughey, 2012 [6] \\
\hline Blue Jacket & N/A & Valleyfield, Quebec & & Present study \\
\hline Blue Jacket II & N/A & Valleyfield, Quebec & & Present study \\
\hline Blue Jacket Early & N/A & Valleyfield, Quebec & & Present study \\
\hline Sandlover & 2009 & Northern Nebraska & $36-40$ & Vermerris, 2008 [15] \\
\hline \multicolumn{5}{|l|}{ Big bluestem } \\
\hline Prairie view & 1994 & 20 sites across Indiana & $38-41$ & Samson et al., 2014 [32] \\
\hline Prairie view II & N/A & Valleyfield, Quebec & & Present study \\
\hline Prairie view Early & N/A & Valleyfield, Quebec & & Present study \\
\hline
\end{tabular}

2.2. Field Management and Data Collection. Plots were arranged in a randomized complete block design with four replications at two sites in Southern Quebec, Sainte-Anne-deBellevue $\left(45^{\circ} 25^{\prime} 32.45^{\prime \prime} \mathrm{N}, 73^{\circ} 55^{\prime} 48.63^{\prime \prime} \mathrm{W}, 37 \mathrm{~m}\right.$ elevation $)$ and Cookshire-Eaton $\left(45^{\circ} 20^{\prime} 57.49^{\prime \prime} \mathrm{N}, 71^{\circ} 47^{\prime} 08.40^{\prime \prime} \mathrm{W}, 243 \mathrm{~m}\right.$ elevation). Plot size was $4 \times 5 \mathrm{~m}$ in Sainte-Anne-de-Bellevue and $2.4 \times 5 \mathrm{~m}$ in Cookshire-Eaton. The soil at the Sainte-Anne-deBellevue site was a free-draining St. Bernard sandy clay loam, while the Cookshire-Eaton site was an imperfectly drained Magog stony loam. All selections of both species were seeded in spring 2010 using a Fabro precision planter (Fabro Enterprises, Swift Current, SK, Canada) with an $18 \mathrm{~cm}$ row spacing. The seeding rate used for all selections was 300 pure live seeds (PLS) $\mathrm{m}^{-2}$. Nitrogen was applied at both sites as urea at a rate of $50 \mathrm{~kg} \mathrm{~N} \mathrm{ha}^{-1}$ in May of 2011 and 2012; no other fertilization was done.

Plant height was determined in each plot biweekly from May to September in 2011 and 2012. The height of 10 plants was measured in each of three subplots selected at random within each plot, with the height recorded as the tallest overall part of the plant. Tiller numbers were also determined biweekly in 2011 and 2012 in three $50 \times 50 \mathrm{~cm}$ quadrats placed randomly in each plot. Tiller counts were continued until tiller dies down at the beginning of the transition to dormancy at the end of each growing season. Phenology stages were determined based on sampling 10 plants at random from each plot and was scored based on the mean stage count (MSC) as described by Moore et al. [34]. Big bluestem selections were not included in tiller counts and were measured for height once at the end of the growing season.

All plots were harvested in the fall after a first frost using a flail-type forage harvester with a cutting surface of $0.6 \times 5 \mathrm{~m}$ and a cutting height of $7 \mathrm{~cm}$. The harvest dates for 2011 and 2012 were November 1 and October 23 in Sainte-Anne-deBellevue and October 24 and October 17 in Cookshire-Eaton, respectively. In addition, the selections from "Cave-in-Rock" switchgrass and "Prairie View Indiana" big bluestem were also harvested in the spring to determine yield differences related to harvest time. The 2012 spring harvest dates were April 19 and April 30 in Sainte-Anne-de-Bellevue and CookshireEaton, respectively. All harvested biomass was weighed and subsamples of approximately $500 \mathrm{~g}$ were collected from each plot to determine biomass yield on a dry matter basis. These subsamples were also used to determine the moisture, ash, fiber, and energy concentration of the harvested biomass for selections that were harvested both in the fall and in the spring.

2.3. Laboratory Analyses. Subsamples taken from each plot were dried for 48 hours at $60^{\circ} \mathrm{C}$ and then reweighed to determine moisture concentration [35] (method number 934.01). Dry samples were then ground with a Model 4 ThomasWiley Laboratory Mill forage grinder (Thomas Scientific, Swedesboro, NJ, USA) to pass through a $1 \mathrm{~mm}$ screen. The ash fraction was determined using a Thermolyne (Dubuque, IA, USA) muffle furnace [35] (method number 924.05). Ground samples were analyzed for neutral (NDF) and acid (ADF) detergent fiber using an Ankom Fiber Analyzer (Ankom Technology Corporation, Macedon, NY, USA) by incubating the samples in neutral [35] and acid detergent solutions [35] (method number 9738.18), respectively. Acid digestible lignin (ADL) was determined by washing ADF residues with $20 \mathrm{~N}$ $\mathrm{H}_{2} \mathrm{SO}_{4}$ [35] (method number 9738.18). From the results of these analyses cellulose, hemicellulose, and lignin concentrations were calculated (hemicellulose $=\mathrm{NDF}-\mathrm{ADF}$, cellulose $=\mathrm{ADF}-\mathrm{ADL}$, and lignin $=\mathrm{ADL}-$ mineral ash) [36]. Energy concentration was determined using a Parr adiabatic bomb calorimeter (Parr Oxygen Bomb Model 1341EB, Calorimeter Thermometer Model 6772, Parr Instrument Company, Moline, IL, USA) to calculate higher heating value (HHV). 
TABLE 2: Yield on dry matter basis of 11 selections of switchgrass and 3 selections of big bluestem seeded in 2010 and harvested in fall of 2011 and 2012 at two sites in Southern Quebec (in $\mathrm{Mg} \mathrm{ha}^{-1}$ ).

\begin{tabular}{|c|c|c|c|c|}
\hline \multirow{2}{*}{ Entry } & \multicolumn{2}{|c|}{ Sainte-Anne-de-Bellevue } & \multicolumn{2}{|c|}{ Cookshire-Eaton } \\
\hline & 2011 & 2012 & 2011 & 2012 \\
\hline \multicolumn{5}{|l|}{ Switchgrass } \\
\hline Sunburst & 7.7 & 9.1 & 3.6 & 5.6 \\
\hline Blue Jacket & 9.0 & 9.1 & 4.2 & 4.8 \\
\hline Blue Jacket II & 9.7 & 9.1 & 5.0 & 5.3 \\
\hline Blue Jacket Early & 8.1 & 9.1 & 3.6 & 4.7 \\
\hline Summer & 9.2 & 11.2 & 4.9 & 6.8 \\
\hline Tecumseh & 8.2 & 10.4 & 2.1 & 4.2 \\
\hline Tecumseh II & 9.3 & 10.3 & 4.6 & 6.7 \\
\hline Cave-in-Rock & 10.0 & 10.3 & 3.5 & 7.3 \\
\hline Cave-in-Rock II & 10.2 & 11.1 & 5.9 & 9.0 \\
\hline Cave-in-Rock Early & 8.8 & 9.9 & 2.5 & 6.4 \\
\hline Sandlover & 9.3 & 9.7 & 1.6 & 5.3 \\
\hline Switchgrass mean & 9.0 & 9.9 & 3.8 & 6.0 \\
\hline \multicolumn{5}{|l|}{ Big Bluestem } \\
\hline Prairie view & 6.0 & 7.5 & 2.1 & 5.1 \\
\hline Prairie view II & 5.6 & 8.8 & 1.9 & 5.6 \\
\hline Prairie view Early & 6.6 & 8.4 & 1.6 & 6.1 \\
\hline Big bluestem mean & 6.1 & 8.2 & 1.9 & 5.6 \\
\hline Overall mean & 8.4 & 9.6 & 3.4 & 5.9 \\
\hline$P$ value & $<0.0001$ & 0.0046 & $<0.0001$ & 0.0004 \\
\hline LSD (5\%) & 1.1 & 1.7 & 1.4 & 1.6 \\
\hline
\end{tabular}

2.4. Statistical Analyses. The experiment design used at both sites was a randomized complete block design with four replications. All data were analyzed using the GLM procedure of the SAS statistical software program [37]. Data were analyzed separately for each environment due to differences in sampling time and sampling numbers. Replicates were considered random effects and treatments (i.e., selections or harvest time (fall versus spring)) were considered fixed. Unless otherwise noted, tests were considered significant at the 5\% probability level. Comparisons between means were made using LSD when ANOVAs indicated significant model and treatment effects. Only significant results are discussed in the text unless otherwise noted.

\section{Results and Discussion}

3.1. Biomass Yield. Switchgrass biomass yield across selections, years, and sites averaged $7.2 \mathrm{Mgha}^{-1}$ with individual site-year averages ranging between 3.8 and $9.9 \mathrm{Mg} \mathrm{ha}^{-1}$ (Table 2). Large differences were observed between sites, with yields averaging 4.9 and $9.5 \mathrm{Mg} \mathrm{ha}^{-1}$ across years in Cookshire-Eaton and Sainte-Anne-de-Bellevue, respectively. Yields of all selections were greater in Sainte-Anne-deBellevue than in Cookshire-Eaton, although differences in the ranking of selections varied at the two sites. Overall much lower yields were observed in Cookshire-Eaton which may have been due to several environmental factors. The Cookshire-Eaton site is less productive as it is at a higher elevation and has a heavier, imperfectly drained soil. It also suffered more intense perennial weed pressure as compared to the Sainte-Anne-de-Bellevue site. The switchgrass and especially the big bluestem appeared to take longer to become established at the Cookshire-Eaton site. The mean switchgrass yield at Sainte-Anne-de-Bellevue increased by $10 \%$ in year 2 while the mean switchgrass yield at Cookshire Eaton increased by $58 \%$ in year 2. Mean big bluestem yields increased by $34 \%$ and $294 \%$ in year 2 at the Sainte-Annede-Belle-vue and Cookshire-Eaton sites, respectively. Overall it appeared that yields are not optimized for switchgrass until the second production year with most selections on productive sites. In the case of switchgrass and especially big bluestem on more marginal sites it may take until year three for the stands to become fully productive as very large increases were experienced in year 2. Amongst the switchgrass accessions tested "Blue Jacket II" appeared to establish very well and had similar yields in both the first and the second year at both sites. This may have been a result of Blue Jacket II's larger seed size [32, 38] and relatively early maturity. These characteristics may allow it to more fully complete its growth cycle in the establishment year. Switchgrass usually reaches $33-66 \%$ of its yield potential in the first production year, while the second production year is generally indicative of long-term biomass yield potential [21]. Overall it appeared that, in the case of a productive site in southern Quebec, a large seeded upland cultivar selected for improved establishment could achieve near full productivity 


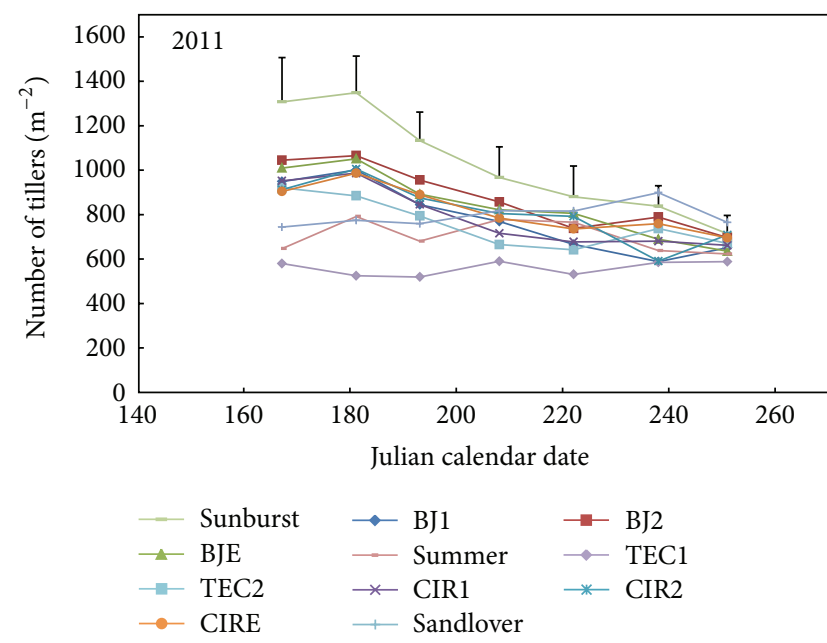

(a)

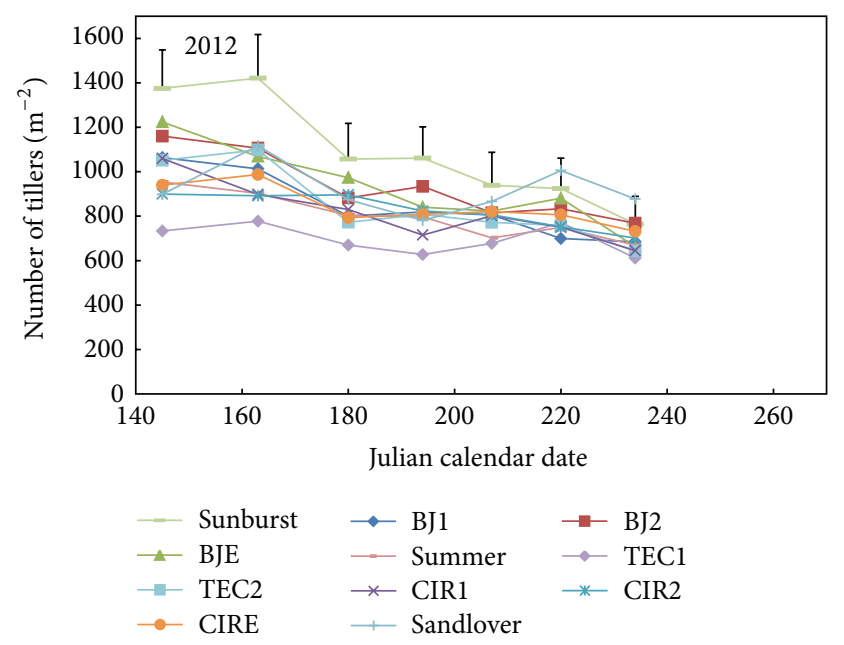

(b)

FIGURE 1: Number of tillers $\mathrm{m}^{-2}$ of 11 selections of switchgrass at Sainte-Anne-de-Bellevue, Quebec, in 2011 and 2012 . Vertical bars represent the least significant difference (LSD, $P=0.05$ ) at each sampling point throughout the season. BJ1, Blue Jacket; BJ2, Blue Jacket II; BJE, Blue Jacket Early; TEC1, Tecumseh; TEC2, Tecumseh II; CIR, Cave-in-Rock; CIR2, Cave-in-Rock II; CIRE, Cave-in-Rock Early.

in the first production year. In the case of big bluestem on a marginal site, as little as $1 / 4$ of the productive potential may be achieved in the first production year.

Variation in switchgrass biomass yield across sites, varieties, and fertilizer regimes has previously been reported [39$42]$, with a recent meta-analysis reporting a mean yield of $8.7 \pm 4.2 \mathrm{Mg} \mathrm{ha}^{-1}$ over 39 trials conducted across the United States [43]. Jannasch et al. [44] reported an average plot yield of $9.2 \mathrm{Mgha}^{-1}$ for switchgrass in Southern Quebec, while average yields of 7.0 and $9.0 \mathrm{Mg} \mathrm{ha}^{-1}$ were reported in Minnesota [45] and Iowa [39], respectively.

Big bluestem biomass yields averaged $5.5 \mathrm{Mg} \mathrm{ha}^{-1}$ across all selections, sites, and years and were more variable than switchgrass, with values ranging between 1.9 and $8.2 \mathrm{Mg} \mathrm{ha}^{-1}$ in individual site-years. Previous experiences have suggested that big bluestem may not reach its maximum yield potential until 3-4 years after seeding [15], a result supported by the large increases in yield and plant height observed between years in the present study.

Differences in switchgrass biomass yield were also observed between selections. Overall yields followed similar patterns as previous studies with early maturing cultivars generally being lower yielding selections than later maturing selections [46] (Table 2). However, higher yields for some of the most recent selections were observed when compared to the original parent materials. For example "Cave-in-Rock II" outyielded Cave-in-Rock in both years at Cookshire-Eaton, while "Blue Jacket II" outyielded "Sunburst" at both sites in 2011. In the case of Tecumseh II there were no significant differences in yield with "Summer" switchgrass observed. "Summer" is known to be a relatively high producing cultivar for its maturity class and breeding progress may be more difficult to achieve. The "Cave-in-Rock II" selection overall appeared to be amongst the most productive selections across sites and years. "Cave-in-Rock" selections generally performed at least as well as or better than the other selections tested, confirming the results of other studies which have found "Cave-in-Rock" to be well adapted and high yielding in Southern Quebec [47].

Some selections from the "Sunburst" variety performed poorly in Cookshire-Eaton and in both 2011 and 2012 significantly higher stem rust (Puccinia spp.) incidence was noted on those selections relative to all other selections in the study (data not shown). Stem rust infections are the most common disease reported in switchgrass and may cause significant damage including stunting, early flowering, and reduced yield [39]. The prevalence of rust infections on all "Cavein-Rock" selections was extremely low, as seen in previous research [48]. Gustafson et al. [49] evaluated the genetic variation in resistance to rust disease in switchgrass populations including "Summer," "Sunburst," and "Cave-in-Rock." "Sunburst" had the highest susceptibility to rust, while "Cavein-Rock," having evolved under heavy rust pressure in humid Southern Illinois, was the least susceptible.

3.2. Tiller Density. Significant differences in tiller number were observed among selections at all measurement points in both years at Sainte-Anne-de-Bellevue (Figure 1). At the first measurement period (early June in 2011 and late May in 2012), the mean tiller density per square meter across all entries was 906 in 2011 and increased to 1033 in 2012, with "Sunburst" producing the most tillers $\mathrm{m}^{-2}$ in both years (1307 in 2011 and 1375 in 2012). Low tiller counts were observed on "Tecumseh" and "Sandlover" switchgrass in 2011 as the plots had relatively thin plant stands. Due to the large variability between plots, the significant differences observed were often between selection lineages and not between selections within a lineage. By the end of August, tiller density in Sainte-Anne-deBellevue had decreased to 674 and 706 tillers per square meter in 2011 and 2012, respectively, representing average decreases of $22 \%$ and $30 \%$, respectively. The magnitude of the decrease 


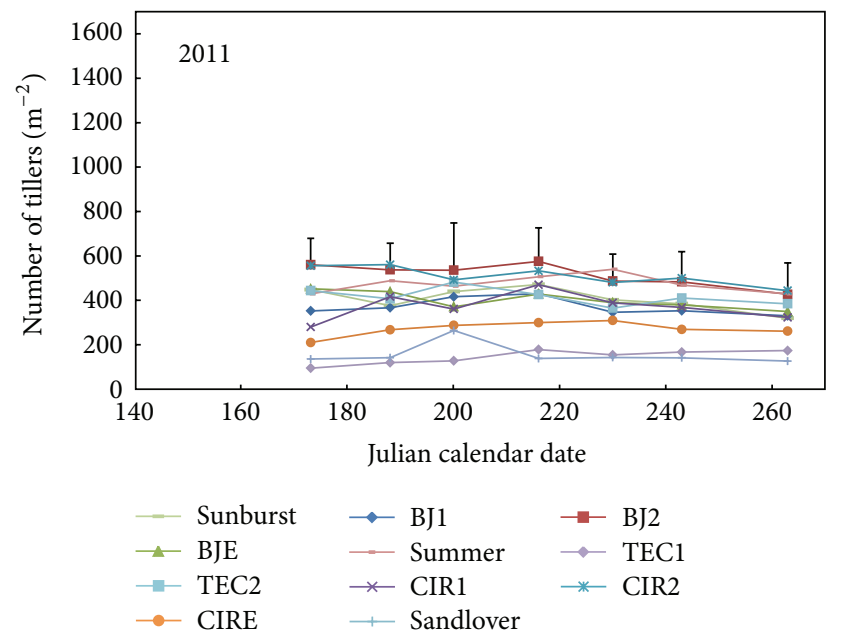

(a)

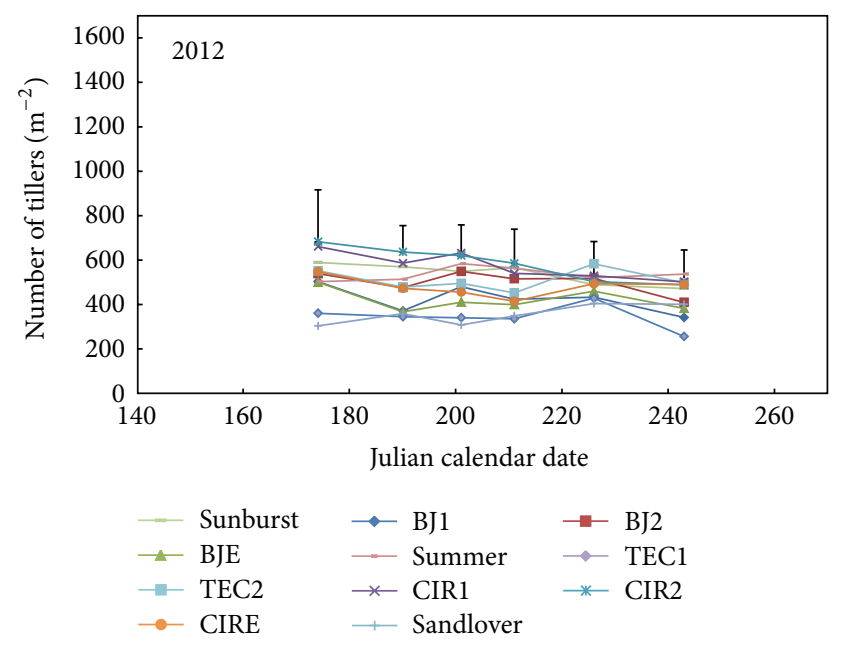

(b)

FIGURE 2: Number of tillers $\mathrm{m}^{-2}$ of 11 selections of switchgrass at Cookshire-Eaton, Quebec, in 2011 and 2012. Vertical bars represent the least significant difference (LSD, $P=0.05$ ) at each sampling point throughout the season. BJ1, Blue Jacket; BJ2, Blue Jacket II; BJE, Blue Jacket Early; TEC1, Tecumseh; TEC2, Tecumseh II, CIR; Cave-in-Rock; CIR2, Cave-in-Rock II; CIRE, Cave-in-Rock Early.

varied considerably depending on the selection lineage. The average decrease in tiller density throughout the season across both years was 38\% for "Sunburst" selections, $26 \%$ for "Cave-in-Rock" selections, and 19\% for "Summer" selections, while no decrease was observed for "Sandlover" which had a thin stand. All selections from the "Sunburst" lineage displayed reduced tillering early in the season. The variable degree of tiller loss across selections ultimately had an equalizing effect on tiller density between all selections.

In Cookshire-Eaton stands were considerably thinner and more variable, but significant differences were still observed between selections at all measurement periods (Figure 2). At both sites differences between selections were much larger at the beginning of the season, with only stands with the highest initial density self-thinning throughout the season. However, due to the thinner stands at CookshireEaton tiller mortality during the season was greatly reduced. In 2011, the low initial tiller density in Cookshire-Eaton resulted in no significant decrease over the course of the season with mean tiller number across all selections decreasing from 360 to 324 tillers $\mathrm{m}^{-2}$. In 2012 all stands had higher initial tiller density and a correspondingly greater decrease from 522 to 434 tillers $\mathrm{m}^{-2}$, an average decrease of $14 \%$ over the season. Once stands had more fully established at the Cookshire-Eaton site in 2012, trends in average tiller decrease also began to align more closely with those seen at SainteAnne-de-Bellevue with an average decrease of $25 \%$ for "Sunburst" selections, $21 \%$ for "Cave-in-Rock" selections, and $11 \%$ for "Summer" selections, while "Sandlover" did not decrease at all due to a thin stand.

High tiller mortality as the growing season progresses is common in grasses, with crops such as ryegrass losing $60 \%$ of their tillers [50]. The large majority of these are small vegetative tillers which senesce in the sward after being shaded out by the larger reproductive tillers. In perennial grasses such as switchgrass high vegetative tiller production occurs in the spring with subsequent mortality throughout the season [51].

The results of the present study support previous findings that indicate that there is likely an optimal tiller density for efficient capture of solar radiation which swards target through increased vegetative tiller production or selfthinning. This optimum is known as tiller equilibrium density [23]. Madakadze et al. [52] found that populations of switchgrass had differing leaf area indices associated with various heights of their canopy. The authors also found that leaf angle and leaf area index varied by variety, indicating that different populations have different canopy structures. The variability in tiller mortality among selections in the present study may indicate that tiller plasticity also plays a large role in this variability. Boe and Casler [13] reported a large degree of plasticity in tiller morphology within populations. In the present study this plasticity seemed to allow tiller density across many selections to converge towards equilibrium density. "Sunburst" had the highest initial density and displayed $>40 \%$ tiller mortality over the season (Figures 1 and 2), while conversely "Sandlover," the selection with the lowest initial tiller density, did not display any tiller mortality on average.

A trend was also noted for differences in decrease between selections when compared to their parent variety, appearing to often be due to lower initial tiller density in the selections at the beginning of the season. Redfearn et al. [48] examined tiller density in switchgrass plots in Iowa and Nebraska managed for forage and found $\mathrm{G} \times \mathrm{E}$ interactions to be present for both yield and tiller density, with "Cavein-Rock" producing the lowest tiller number but highest forage yield. The authors noted that tiller density differed with location, even between selections from the same base population. In the present study at Sainte-Anne-de-Bellevue average tiller mortality over both years was 10\% lower in "Blue Jacket II" than in "Sunburst" and 13\% lower in "Cave-in-Rock II" than in the "Cave-in-Rock" base population. However, 


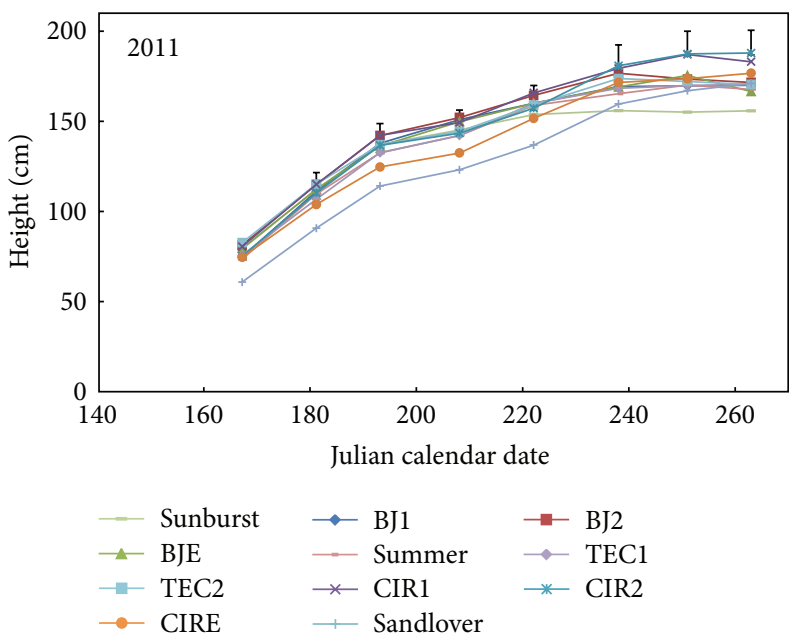

(a)

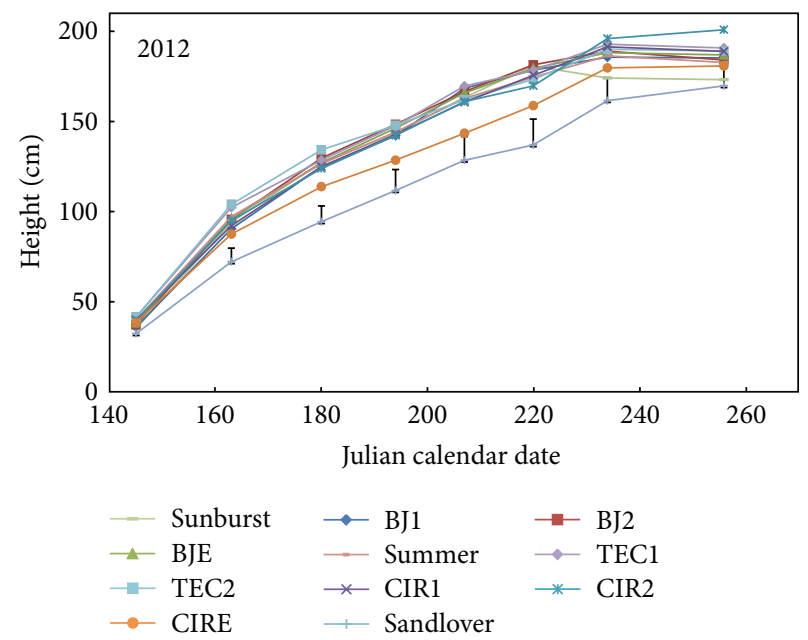

(b)

Figure 3: Height of 11 selections of switchgrass at Sainte-Anne-de-Bellevue, Quebec, in 2011 and 2012. Vertical bars represent the least significant difference (LSD, $P=0.05$ ) at each sampling point throughout the season. BJ1, Blue Jacket; BJ2, Blue Jacket II; BJE, Blue Jacket Early; TEC1, Tecumseh; TEC2, Tecumseh II; CIR, Cave-in-Rock; CIR2, Cave-in-Rock II; CIRE, Cave-in-Rock Early.

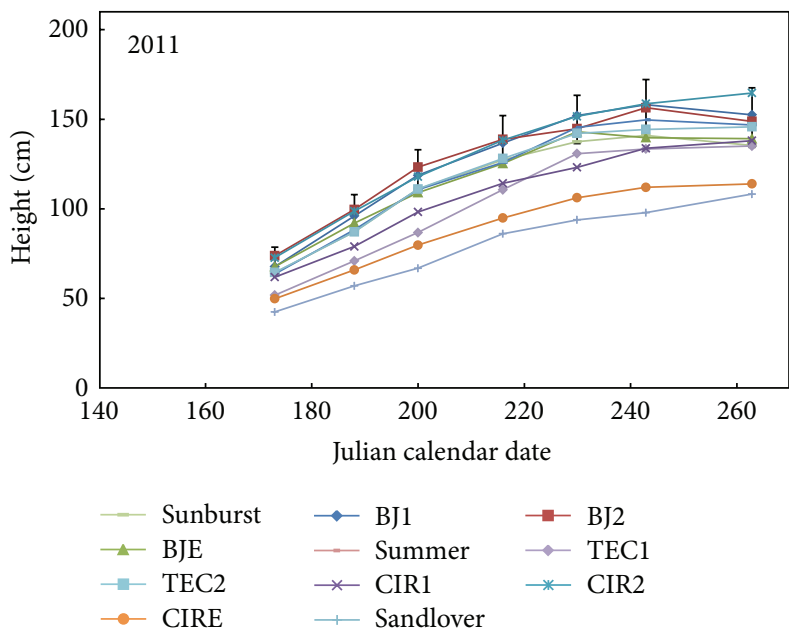

(a)

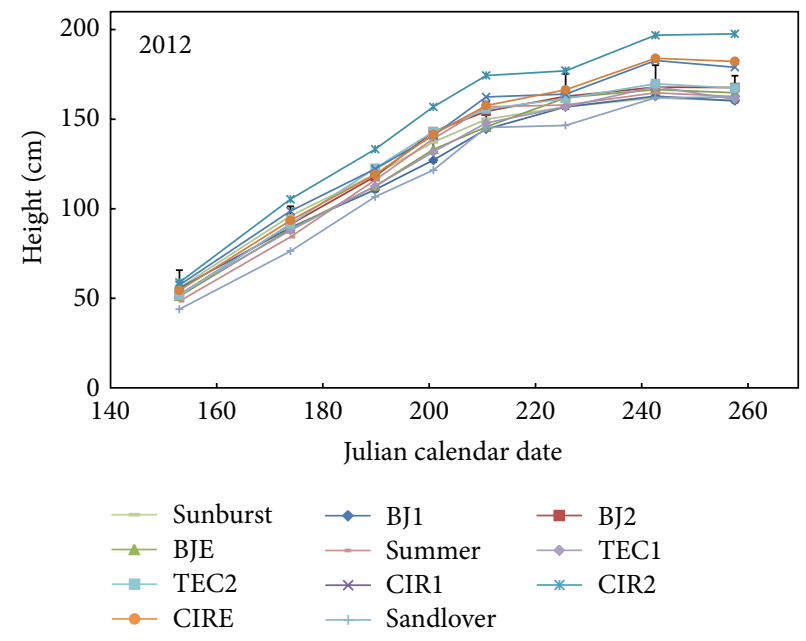

(b)

FIGURE 4: Height of 11 selections of switchgrass at Cookshire-Eaton, Quebec, in 2011 and 2012. Vertical bars represent the least significant difference (LSD, $P=0.05$ ) at each sampling point throughout the season. BJ1, Blue Jacket; BJ2, Blue Jacket II; BJE, Blue Jacket Early; TEC1, Tecumseh; TEC2, Tecumseh II; CIR, Cave-in-Rock; CIR2, Cave-in-Rock II; CIRE, Cave-in-Rock Early.

there was an average increase in tiller loss in the "Summer" lineage, with mortality on average $16 \%$ higher in "Tecumseh II" than in "Summer." This was likely due to "Tecumseh II" establishing more quickly and having a higher initial density than "Summer" in 2011. In 2012 the "Summer" population was more fully established and there was no significant difference between the two. These trends suggest progress in modification of tillering among the selection lineages where populations were well established.

3.3. Height. Significant differences were observed between the heights of selections at all periods observed throughout all site-years (Figures 3 and 4); however, trends varied by site. The trends observed were generally supported by previous studies which have indicated that later maturing varieties produce taller tillers due to their slower rates of leaf appearance [53]. "Cave-in-Rock II" was significantly taller than the other selections in its lineage at both sites in 2012, reaching an average of $201 \mathrm{~cm}$ in Sainte-Anne-de-Bellevue. Over all site-years this represented an average increase of $12 \mathrm{~cm}$ or $7 \%$ over the parent variety. The "Cave-in-Rock" selections were the tallest three recorded in 2012 at Cookshire-Eaton. In 2012 the relatively early maturing "Tecumseh" and "Tecumseh II" selections performed very well in Sainte-Anne-de-Bellevue, 


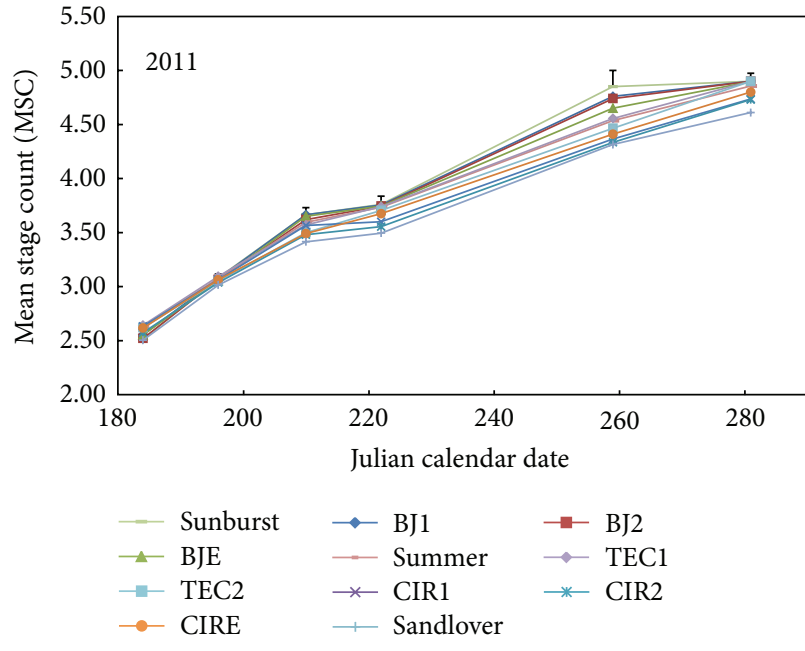

(a)

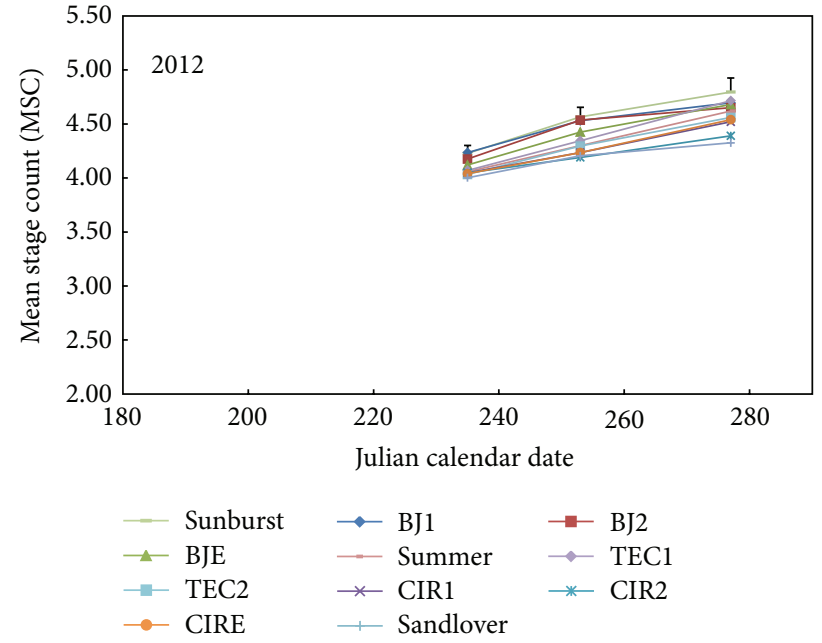

(b)

Figure 5: Mean stage count of 11 selections of switchgrass at Sainte-Anne-de-Bellevue, Quebec, in 2011 and 2012. Vertical bars represent the least significant difference (LSD, $P=0.05$ ) at each sampling point throughout the season. BJ1, Blue Jacket; BJ2, Blue Jacket II; BJE, Blue Jacket Early; TEC1, Tecumseh; TEC2, Tecumseh II; CIR, Cave-in-Rock; CIR2, Cave-in-Rock II; CIRE, Cave-in-Rock Early.

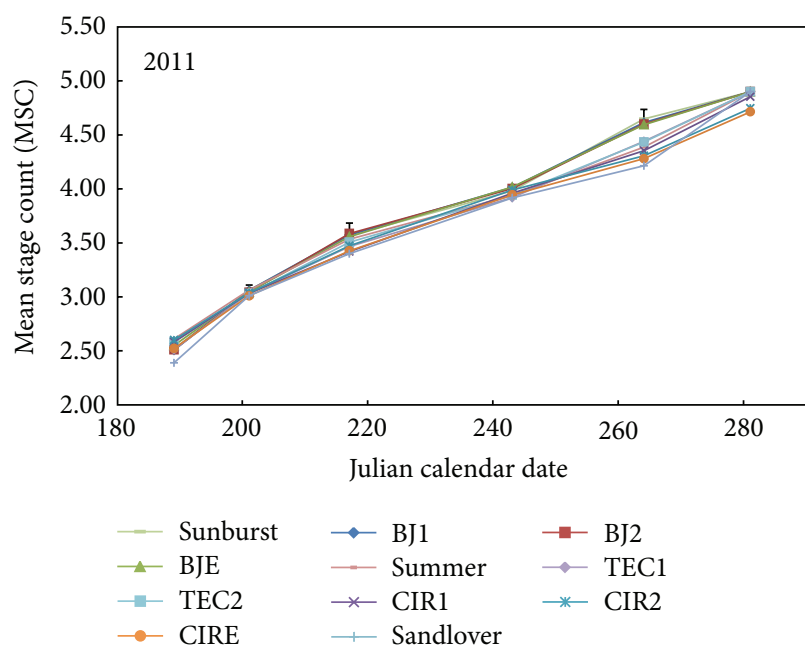

(a)

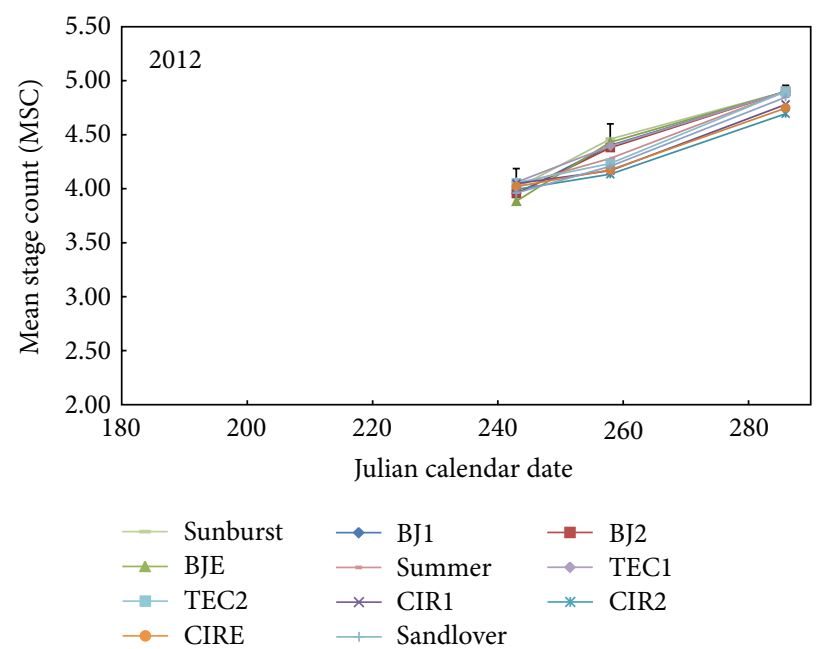

(b)

FIgURE 6: Mean stage count of 11 selections of switchgrass at Cookshire-Eaton, Quebec, in 2011 and 2012. Vertical bars represent the least significant difference (LSD, $P=0.05$ ) at each sampling point throughout the season. BJ1, Blue Jacket; BJ2, Blue Jacket II; BJE, Blue Jacket Early; TEC1, Tecumseh; TEC2, Tecumseh II; CIR, Cave-in-Rock; CIR2, Cave-in-Rock II; CIRE, Cave-in-Rock Early.

attaining the second and third highest average heights; however, there was no significant increase in height over the parent variety "Summer."

No meaningful height differences were observed among big bluestem selections (data not shown); however, there was a significant increase in height in the second year at both sites. This result is consistent with the slower establishment in big bluestem. Average height increased from 144 to $192 \mathrm{~cm}(33 \%)$ at the Cookshire-Eaton site and from 194 to $216 \mathrm{~cm}(11 \%)$ at Sainte-Anne-de-Bellevue in 2011 and 2012, respectively.
3.4. Maturity. There were significant differences observed in phenological development at both sites for all measurement periods (Figures 5 and 6). The differences observed were almost exclusively between selections in different selection lineages and not within a lineage. The "Sunburst" selections displayed the earliest maturity, followed by the "Summer" selections, with the "Cave-in-Rock" and "Sandlover" selections displaying the latest maturity. These findings are supported by recent literature linking latitude of origin with maturity $[46,54]$. The latitudes of origin of the selections in 
TABLE 3: Moisture concentration (\%) at fall harvest of 11 selections of switchgrass and 3 selections of big bluestem at two sites in Southern Quebec.

\begin{tabular}{|c|c|c|c|c|}
\hline \multirow{2}{*}{ Entry } & \multicolumn{2}{|c|}{ Sainte-Anne-de-Bellevue } & \multicolumn{2}{|c|}{ Cookshire-Eaton } \\
\hline & 2011 & 2012 & 2011 & 2012 \\
\hline \multicolumn{5}{|l|}{ Switchgrass } \\
\hline Sunburst & 36.8 & 34.1 & 33.8 & 27.6 \\
\hline Blue Jacket & 36.1 & 33.8 & 31.6 & 31.8 \\
\hline Blue Jacket II & 35.5 & 35.4 & 32.7 & 30.1 \\
\hline Blue Jacket Early & 38.1 & 35.2 & 30.1 & 28.0 \\
\hline Summer & 39.7 & 31.9 & 26.1 & 24.4 \\
\hline Tecumseh & 37.7 & 35.8 & 37.5 & 29.3 \\
\hline Tecumseh II & 40.3 & 34.3 & 31.4 & 20.2 \\
\hline Cave-in-Rock & 46.1 & 41.0 & 43.6 & 29.8 \\
\hline Cave-in-Rock II & 45.8 & 44.5 & 44.9 & 39.6 \\
\hline Cave-in-Rock Early & 44.1 & 41.8 & 35.5 & 31.6 \\
\hline Sandlover & 49.1 & 44.5 & 38.7 & 34.8 \\
\hline Switchgrass mean & 40.8 & 37.5 & 35.1 & 29.7 \\
\hline \multicolumn{5}{|l|}{ Big Bluestem } \\
\hline Prairie view & 43.7 & 39.6 & 44.3 & 38.9 \\
\hline Prairie view II & 46.8 & 41.0 & 35.6 & 30.9 \\
\hline Prairie view Early & 43.8 & 39.0 & 44.0 & 33.7 \\
\hline Big bluestem mean & 44.8 & 39.9 & 41.3 & 34.5 \\
\hline Overall mean & 41.7 & 38.0 & 36.4 & 30.8 \\
\hline$P$ value & $<0.0001$ & $<0.0001$ & 0.0002 & 0.0023 \\
\hline LSD (5\%) & 3.3 & 3.2 & 7.9 & 7.6 \\
\hline
\end{tabular}

this study rank in the same order as the maturity observed (Table 1). The moisture concentration of the selections at harvest also mirrored this pattern, with significant differences observed between selections related to maturity at harvest (Table 3). No significant moisture differences were observed between selections from a same parent variety.

3.5. Effects of Harvest Date on Biomass Yield and Quality Variables. Differences were observed at both sites for some selections between fall and spring harvest dates for yield, moisture concentration, and cellulose concentration (Tables 4 and 5). The Sainte-Anne-de-Bellevue spring harvest resulted in an overall $41 \%$ yield reduction compared to a fall harvest. In Cookshire-Eaton a spring harvest only reduced yield in the highest-yielding selection, "Cave-in-Rock II", which had an average loss of $56 \%$. Reductions of up to $40 \%$ in biomass yield have also been reported in Pennsylvania, where this yield loss was attributed to the loss of panicles and leaves, the leaching of stem components such as minerals and cell solubles [27], and the translocation of mobile nutrients and N-rich compounds into underground perennial structures, a process which may continue into December [3]. These processes have also been shown to decrease the ash fraction in the spring $[27,28]$. In the present study no differences were observed between ash concentrations of spring versus fall harvested material (Tables 4 and 5). This lack of change in ash concentration may have been due to soil contamination from the grasses overwintering on the site in a lodged state. Current best management practice by farmers in Eastern Canada is to mow the grasses in late fall and to bale the biomass in spring. This system helps to reduce biomass losses by minimizing the breakage of the leaves and seed heads resulting from wind and snow exposure in material standing over winter [55]. Small plot studies may, therefore, overestimate yield losses compared to an on-farm spring harvest regime. In this study the yield and quality comparisons of the fall and spring material were only made on first production year (2nd year after seeding) material, which had not yet reached full establishment at the marginal site.

The decrease in moisture concentration in the spring biomass compared to the fall averaged $74 \%$ across selections and sites, falling from $45 \%$ to $11 \%$ moisture concentration (Table 4). The high fall moisture values for "Cave-in-Rock" selections are a result of its late maturity and high biomass production. Plant materials are difficult to dry in the short, cool, and high humidity days in Eastern Canada in the late fall [31]. The calorific value for combustion of herbaceous biomass declines linearly with rising moisture concentration, making this an important measure for certain applications [56]. Drying can also take place in covered storage, with fallbaled material at $16-17 \%$ moisture declining to $12-14 \%$ by the following spring [31].

The cell walls of grasses contain cellulose, hemicellulose, lignin, and other compounds including p-coumaric, phenolic, and ferulic acids $[26,57]$. The increase in cellulose concentration for some selections at both sites (Tables 4 and 5) is likely related to increased stem fraction combined with an overall reduction of mineral and cell soluble concentrations 
TABLE 4: Fall 2011 and spring 2012 values on dry matter basis for yield, moisture concentration, cell wall components, ash, and higher heating value (HHV) of three selections of switchgrass and three selections of big bluestem in Sainte-Anne-de-Bellevue, Quebec.

\begin{tabular}{|c|c|c|c|c|c|c|c|c|c|}
\hline Entry & & CIR & CIR2 & CIRE & $\mathrm{PV}$ & PV2 & PVE & $P$ value & LSD \\
\hline \multirow{5}{*}{ Moisture (\%) } & Fall & 46.1 & 45.8 & 44.1 & 43.7 & 46.8 & 43.8 & 0.1843 & 3.076 \\
\hline & Spring & 11.2 & 14 & 10.6 & 10.7 & 11.5 & 10.9 & 0.326 & 3.411 \\
\hline & $\%$ change $^{\dagger}$ & -75.7 & -69.4 & -76 & -75.4 & -75.4 & -75.1 & & \\
\hline & $P$ value & 0.0001 & $<0.0001$ & 0.0002 & $<0.0001$ & 0.0002 & 0.0002 & & \\
\hline & LSD & 4.209 & 2.812 & 4.925 & 3.737 & 4.706 & 4.2826 & & \\
\hline \multirow{5}{*}{ Yield $\left(\mathrm{Mg} \mathrm{ha}^{-1}\right)$} & Fall & 10 & 10.2 & 8.8 & 6 & 5.6 & 6.6 & $<0.0001$ & 1.202 \\
\hline & Spring & 6.2 & 6.1 & 6.6 & 3.8 & 2.8 & 3 & $<0.0001$ & 1.518 \\
\hline & $\%$ change $^{\dagger}$ & -38.3 & -40.4 & -25.2 & -37.9 & -49.5 & -55.1 & & \\
\hline & $P$ value & 0.0052 & 0.0102 & 0.0493 & 0.053 & 0.0018 & 0.0034 & & \\
\hline & LSD & 1.67 & 2.253 & 2.205 & 2.341 & 0.8374 & 1.3616 & & \\
\hline \multirow{5}{*}{$\begin{array}{l}\text { Cellulose } \\
\left(\mathrm{g} \mathrm{kg}^{-1}\right)\end{array}$} & Fall & 419 & 414 & 389 & 439 & 431 & 438 & 0.0056 & 25.05 \\
\hline & Spring & 456 & 438 & 429 & 476 & 449 & 447 & 0.001 & 17.59 \\
\hline & $\%$ change $^{\dagger}$ & 8.8 & 5.6 & 10.4 & 8.3 & 4.2 & 2.1 & & \\
\hline & $P$ value & 0.0654 & 0.0004 & 0.0042 & 0.029 & 0.1361 & 0.0143 & & \\
\hline & LSD & 41.2 & 4.227 & 16.29 & 29.42 & 28.491 & 5.676 & & \\
\hline \multirow{5}{*}{$\begin{array}{l}\text { Hemicellulose } \\
\left(\mathrm{g} \mathrm{kg}^{-1}\right)\end{array}$} & Fall & 315 & 321 & 324 & 316 & 303 & 300 & 0.0593 & 17.42 \\
\hline & Spring & 324 & 336 & 340 & 291 & 313 & 307 & 0.0005 & 18.97 \\
\hline & $\%$ change $^{\dagger}$ & 2.9 & 4.7 & 4.9 & -7.9 & 3.3 & 2.3 & & \\
\hline & $P$ value & 0.457 & 0.2528 & 0.0061 & 0.056 & 0.209 & 0.1208 & & \\
\hline & LSD & 34.56 & 35.1 & 7.173 & 26.219 & 20.403 & 10.329 & & \\
\hline \multirow{5}{*}{$\operatorname{Lignin}\left(\mathrm{g} \mathrm{kg}^{-1}\right)$} & Fall & 77 & 69 & 65.5 & 60.1 & 62.9 & 63.1 & 0.2727 & 14.94 \\
\hline & Spring & 90.3 & 73.5 & 64.5 & 79.3 & 63.7 & 67.9 & $<0.0001$ & 8.647 \\
\hline & $\%$ change $^{\dagger}$ & 17.3 & 6.5 & -1.5 & 31.9 & 1.3 & 7.6 & & \\
\hline & $P$ value & 0.2283 & 0.3488 & 0.8434 & 0.0094 & 0.8919 & 0.2655 & & \\
\hline & LSD & 28.093 & 12.857 & 14.786 & 9.9 & 16.149 & 11.246 & & \\
\hline \multirow{5}{*}{ Ash $\left(\mathrm{g} \mathrm{kg}^{-1}\right)$} & Fall & 45.2 & 48.9 & 47.4 & 48.2 & 49.1 & 46.3 & 0.9689 & 11.14 \\
\hline & Spring & 50.4 & 53.2 & 50.8 & 48.3 & 50.3 & 55.5 & 0.9601 & 17.25 \\
\hline & $\%$ change $^{\dagger}$ & 11.5 & 8.8 & 7.2 & 0.2 & 2.4 & 19.9 & & \\
\hline & $P$ value & 0.5503 & 0.4563 & 0.2225 & 0.9562 & 0.7607 & 0.1186 & & \\
\hline & LSD & 24.9 & 16.041 & 6.897 & 9.329 & 11.929 & 13.538 & & \\
\hline \multirow{5}{*}{$\mathrm{HHV}\left(\mathrm{MJ} \mathrm{kg}^{-1}\right)$} & Fall & 18.71 & 18.96 & 18.78 & 18.73 & 19 & 18.94 & 0.5896 & 0.4463 \\
\hline & Spring & 18.96 & 18.99 & 18.73 & 18.85 & 18.88 & 18.92 & 0.761 & 0.399 \\
\hline & $\%$ change $^{\dagger}$ & 1.3 & 0.2 & -0.3 & 0.6 & -0.6 & -0.1 & & \\
\hline & $P$ value & 0.4213 & 0.8845 & 0.7915 & 0.4774 & 0.4568 & 0.9009 & & \\
\hline & LSD & 0.887 & 0.5706 & 0.5966 & 0.4781 & 0.46 & 0.4408 & & \\
\hline
\end{tabular}

${ }^{\dagger}$ Percent change relative to fall value.

CIR, Cave-in-Rock; CIR2, Cave-in-Rock II; CIRE, Cave-in-Rock Early; PV, Prairie view; PV2, Prairie view II; PVE, Prairie view Early.

in overwintered materials. Whole plant big bluestem tended to have slightly higher cellulose and lower hemicellulose concentrations than switchgrass, again likely due to increased stem fraction in the big bluestem. Overwintering generally had a tendency to increase concentration of cellulose in both switchgrass and big bluestem. If big bluestem genetics can be improved to produce similar yields to switchgrass it could be a promising species where high cellulose content biomass feedstocks are required for markets such as bioethanol production and biofibre applications. For lignin there were no trends evident between species or selections. Overall big bluestem appeared to have a higher cellulose to hemicellulose ratio than upland switchgrass. This could be of interest for specialty applications requiring high cellulose content feedstocks.

There were no differences in HHV observed between selections or between harvest dates, with Sainte-Anne-deBellevue and Cookshire-Eaton averaging 18.9 and $19.3 \mathrm{~kJ} \mathrm{~g}^{-1}$, respectively, over both harvest times. A previous analysis of four varieties of fall-harvested switchgrass determined an average energy concentration of $18.8 \pm 0.2 \mathrm{~kJ} \mathrm{~g}^{-1}$ with no 
TABLE 5: Fall of 2011 and spring of 2012 values on dry matter basis for yield, moisture concentration, cell wall components, ash, and higher heating value (HHV) of three selections of switchgrass and three selections of big bluestem in Cookshire-Eaton, Quebec.

\begin{tabular}{|c|c|c|c|c|c|c|c|c|c|}
\hline Entry & & CIR & CIR2 & CIRE & $\mathrm{PV}$ & PV2 & PVE & $P$ value & LSD \\
\hline \multirow{5}{*}{ Moisture (\%) } & Fall & 43.6 & 44.9 & 35.5 & 44.3 & 35.6 & 43.9 & 0.0962 & 8.8360 \\
\hline & Spring & 8.5 & 8.8 & 7.3 & & & & & \\
\hline & $\%$ change $^{\dagger}$ & -80.4 & -80.3 & -79.5 & & & & & \\
\hline & $P$ value & 0.0007 & 0.001 & 0.0106 & & & & & \\
\hline & LSD & 3.8578 & 4.8707 & 12.587 & & & & & \\
\hline \multirow{5}{*}{ Yield $\left(\mathrm{Mg} \mathrm{ha}^{-1}\right)$} & Fall & 3.5 & 5.9 & 2.5 & 2.1 & 1.9 & 1.6 & 0.0002 & 1.2830 \\
\hline & Spring & 2.6 & 2.6 & 2.3 & 0.0 & 0.0 & 0.0 & & \\
\hline & $\%$ change $^{\dagger}$ & -26.2 & -56.3 & -8.5 & -100.0 & -100.0 & -100.0 & & \\
\hline & $P$ value & 0.2539 & 0.0188 & 0.6558 & & & & & \\
\hline & LSD & 2.5201 & 1.9826 & 1.7471 & & & & & \\
\hline \multirow{5}{*}{$\begin{array}{l}\text { Cellulose } \\
\left(\mathrm{g} \mathrm{kg}^{-1}\right)\end{array}$} & Fall & 415 & 396 & 376 & 385 & 381 & 371 & 0.2719 & 40.852 \\
\hline & Spring & 445 & 454 & 415 & & & & 0.001 & 10.307 \\
\hline & $\%$ change $^{\dagger}$ & 7.2 & 14.7 & 10.3 & & & & & \\
\hline & $P$ value & 0.3218 & 0.1236 & 0.0132 & & & & & \\
\hline & LSD & 98.893 & 97.169 & 19.321 & & & & & \\
\hline \multirow{5}{*}{$\begin{array}{l}\text { Hemicellulose } \\
\left(\mathrm{g} \mathrm{kg}^{-1}\right)\end{array}$} & Fall & 352 & 317 & 339 & 316 & 301 & 290 & 0.0088 & 29.914 \\
\hline & Spring & 345 & 304 & 333 & & & & 0.0001 & 6.325 \\
\hline & $\%$ change $^{\dagger}$ & -1.7 & -4.0 & -1.7 & & & & & \\
\hline & $P$ value & 0.3591 & 0.2353 & 0.2808 & & & & & \\
\hline & LSD & 22.334 & 32.475 & 17.053 & & & & & \\
\hline \multirow{5}{*}{$\operatorname{Lignin}\left(\mathrm{g} \mathrm{kg}^{-1}\right)$} & Fall & 73 & 77 & 61 & 55 & 70 & 66 & 0.1155 & 16.628 \\
\hline & Spring & 72 & 89 & 63 & & & & 0.0009 & 6.488 \\
\hline & $\%$ change $^{\dagger}$ & -0.5 & 16.2 & 3.4 & & & & & \\
\hline & $P$ value & 0.9687 & 0.3272 & 0.5228 & & & & & \\
\hline & LSD & 34.118 & 41.443 & 11.684 & & & & & \\
\hline \multirow{5}{*}{ Ash $\left(\mathrm{g} \mathrm{kg}^{-1}\right)$} & Fall & 39 & 48 & 45 & 45 & 46 & 45 & 0.6675 & 11.274 \\
\hline & Spring & 33 & 30 & 32 & & & & 0.0179 & 1.539 \\
\hline & $\%$ change $^{\dagger}$ & -17.5 & -38.0 & -30.2 & & & & & \\
\hline & $P$ value & 0.1626 & 0.0725 & 0.0625 & & & & & \\
\hline & LSD & 13.665 & 22.343 & 15.498 & & & & & \\
\hline \multirow{5}{*}{$\mathrm{HHV}\left(\mathrm{MJ} \mathrm{kg}^{-1}\right)$} & Fall & 19.15 & 19.09 & 19.31 & 19.22 & 19.20 & 19.27 & 0.7519 & 3.452 \\
\hline & Spring & 19.35 & 19.36 & 19.25 & & & & 0.6191 & 3.264 \\
\hline & $\%$ change $^{\dagger}$ & 1.0 & 1.4 & -0.3 & & & & & \\
\hline & $P$ value & 0.158 & 0.4399 & 0.2681 & & & & & \\
\hline & LSD & 0.387 & 1.2138 & 0.1836 & & & & & \\
\hline
\end{tabular}

${ }^{\dagger}$ Percent change relative to fall value.

CIR, Cave-in-Rock; CIR2, Cave-in-Rock II; CIRE, Cave-in-Rock Early; PV, Prairie view; PV2, Prairie view II; PVE, Prairie view Early.

significant differences between varieties [58], while Madakadze et al. [52] reported a lower energy yield of $17.4 \mathrm{~kJ} \mathrm{~g}^{-1}$ for "Cave-in-Rock" harvested in the fall in Southern Quebec.

Turn et al. [59] have indicated that the leaching process that often occurs in the winter increases HHV in herbaceous biomass through removal of inorganic constituents. However, in the present study harvest time had no effect on HHV. Experiences with spring harvested reed canary grass (Phalaris arundinacea L.) in Sweden demonstrated significant reductions in $\mathrm{Cl}, \mathrm{K}, \mathrm{S}$, alkali, ash, and several other important quality factors but curiously also a decrease in HHV [28]. The authors also noted large variation in HHV and ash concentration related to soil type, with clay soils having much lower values than humus rich or sandy soils.

\section{Conclusions}

A two-year field study of elite selections of switchgrass and big bluestem found significant differences among selections for yield, tiller density, height, and maturity. Switchgrass was 
quicker to reach its optimum yield than big bluestem on both productive and marginal sites. Big bluestem was slower to establish and exhibited a higher cellulose content, which was attributed to its high stem content. On both productive and marginal sites switchgrass reached a similar optimum tiller density at the end of the growing season of 690 and 379 tillers $\mathrm{m}^{-2}$, respectively. Tiller mortality throughout the season ranged from 25 to $38 \%$, from 21 to $26 \%$, and from 11 to $19 \%$ on the "Sunburst," "Cave-in-Rock," and "Summer" lineages, respectively, on the two sites. Two of the elite selections of switchgrass ("Blue Jacket II" and "Cave-in-Rock II") derived from lineages with high tiller mortality showed upwards trends in height, yield, and reduction of tiller mortality when compared to their parent materials. The present study is one of the most detailed to date on tiller mortality in upland switchgrass. Selection for reduced tillering appears to be a promising strategy for improving yield and quality of upland switchgrass biomass. The differences in maturity and moisture concentration observed at harvest in the fall appear to correspond to the germplasm latitude of origin, and earlier maturity typically was related to lower moisture concentration at harvest. Delayed spring harvest resulted in a large decrease in moisture concentration and a slight increase in cellulose concentration; however, yield losses approached $40 \%$. Unlike in previous studies the ash concentration was not affected by harvest date, nor was the HHV.

The results of this study indicate that regional selection programmes have the potential to produce improved selections of upland switchgrass for bioenergy and biofibre markets. From a biomass quality standpoint, big bluestem also appears to be a species of significant potential; however, there is a need for plant breeders to focus on improving establishment to enhance its agronomic potential.

\section{Conflict of Interests}

REAP-Canada is a nonprofit registered charity that has developed some of the lines evaluated in the present project; it could, in the future, receive seed royalties if some of these lines are developed commercially. Data management and analysis were independently managed by researchers from McGill University who have no financial interest in the lines evaluated. They did not receive any financial compensation from REAP-Canada to complete this project, which was funded by MAPAQ.

\section{Acknowledgments}

This research was supported by a research grant from the Ministère de l'Agriculture, des Pêcheries, et de l'Alimentation du Québec (MAPAQ) through its Programme de Soutien à l'Innovation en Agroalimentaire. Philippe Seguin also acknowledges financial support from the Centre SEVE.

\section{References}

[1] M. T. Panciera and G. A. Jung, "Switchgrass establishment by conservation tillage: planting date responses of two varieties," Journal of Soil and Water Conservation, vol. 39, pp. 68-70, 1984.
[2] M. A. Liebig, H. A. Johnson, J. D. Hanson, and A. B. Frank, "Soil carbon under switchgrass stands and cultivated cropland," Biomass and Bioenergy, vol. 28, no. 4, pp. 347-354, 2005.

[3] D. J. Parrish and J. H. Fike, "The biology and agronomy of switchgrass for biofuels," Critical Reviews in Plant Sciences, vol. 24, no. 5-6, pp. 423-459, 2005.

[4] R. Samson, S. Mani, R. Boddey et al., "The potential of $\mathrm{C}_{4}$ perennial grasses for developing a global BIOHEAT industry," Critical Reviews in Plant Sciences, vol. 24, no. 5-6, pp. 461-495, 2005.

[5] H. Kludze, B. Deen, A. Weersink, R. van Acker, K. Janovicek, and A. de Laporte, "Impact of land classification on potential warm season grass biomass production in Ontario, Canada," Canadian Journal of Plant Science, vol. 93, no. 2, pp. 249-260, 2013.

[6] P. G. Jefferson and W. P. McCaughey, "Switchgrass (Panicum virgatum L.) cultivar adaptation, biomass production, and cellulose concentration as affected by latitude of origin," ISRN Agronomy, vol. 2012, Article ID 763046, 9 pages, 2012.

[7] K. P. Vogel, G. Sarath, J. Aaron, and R. B. Mitchell, "Switchgrass," in Energy Crops, N. G. Halford and A. Karp, Eds., pp. 341-380, Royal Society of Chemistry, Cambridge, UK, 2011.

[8] M. D. Casler, "Switchgrass breeding, genetics, and genomics," in Switchgrass, A. Monti, Ed., Green Energy and Technology, Springer, London, UK, 2012.

[9] P. G. Jefferson, W. P. Mccaughey, K. May, J. Woosaree, L. MacFarlane, and S. M. Wright, "Performance of American native grass cultivars in the Canadian prairie provinces," Native Plants Journal, vol. 3, pp. 24-33, 2002.

[10] A. Tubeileh, T. J. Rennie, A. Kerr, A. A. Saita, and C. Patanè, "Biomass production by warm-season grasses as affected by nitrogen application in Ontario," Agronomy Journal, vol. 106, pp. 416-422, 2013.

[11] I. C. Madakadze, T. Radiotis, J. Li, K. Goel, and D. L. Smith, "Kraft pulping characteristics and pulp properties of warm season grasses," Bioresource Technology, vol. 69, no. 1, pp. 75-85, 1999.

[12] A. Boe, R. Bortnem, and K. D. Kephart, "Quantitative description of the phytomers of big bluestem," Crop Science, vol. 40, no. 3, pp. 737-741, 2000.

[13] A. Boe and M. D. Casler, "Hierarchical analysis of switchgrass morphology," Crop Science, vol. 45, no. 6, pp. 2465-2472, 2005.

[14] H. G. Jung and K. P. Vogel, "Lignification of switchgrass (Panicum virgatum) and big bluestem (Andropogon gerardii) plant parts during maturation and its effect on fibre degradability," Journal of the Science of Food and Agriculture, vol. 59, pp. 169176, 1992.

[15] W. Vermerris, Genetic Improvement of Bioenergy Crops, Springer, New York, NY, USA, 2008.

[16] B. A. Robertson, P. J. Doran, L. R. Loomis, J. R. Robertson, and D. W. Schemske, "Perennial biomass feedstocks enhance avian diversity," GCB Bioenergy, vol. 3, no. 3, pp. 235-246, 2011.

[17] M. A. Gardiner, J. K. Tuell, R. Isaacs, J. Gibbs, J. S. Ascher, and D. A. Landis, "Implications of three biofuel crops for beneficial arthropods in agricultural landscapes," Bioenergy Research, vol. 3, no. 1, pp. 6-19, 2010.

[18] C. J. Zilverberg, W. C. Johnson, V. Owens et al., "Biomass yield from planted mixtures and monocultures of native prairie vegetation across a heterogeneous farm landscape," Agriculture, Ecosystems \& Environment, vol. 186, pp. 148-159, 2014.

[19] V. R. Mulkey, V. N. Owens, and D. K. Lee, "Management of warm-season grass mixtures for biomass production in South 
Dakota USA," Bioresource Technology, vol. 99, no. 3, pp. 609617, 2008.

[20] USDA-NRCS Elsberry Plant Materials Center, Cave-InRock Switchgrass, (Panicum virgatum L.) Conservation Plant Release Brochure, 1986, http://www.nrcs.usda.gov/Internet/FSE_ PLANTMATERIALS/publications/mopmcrb11259.pdf.

[21] S. B. McLaughlin and L. A. Kszos, "Development of switchgrass (Panicum virgatum) as a bioenergy feedstock in the United States," Biomass \& Bioenergy, vol. 28, no. 6, pp. 515-535, 2005.

[22] A. J. Smart, L. E. Moser, and K. P. Vogel, "Morphological characteristics of big bluestem and switchgrass plants divergently selected for seedling tiller number," Crop Science, vol. 44, no. 2, pp. 607-613, 2004.

[23] K. M. Zarrough, C. J. Nelson, and D. A. Sleper, "Interrelationships between rates of leaf appearance and tillering in selected tall fescue populations," Crop Science, vol. 24, pp. 565-569, 1984.

[24] R. J. Jones, C. J. Nelson, and D. A. Sleper, "Seedling selection for morphological characters associated with yield of tall fescue," Crop Science, vol. 19, pp. 631-634, 1979.

[25] A. J. Smart and L. E. Moser, "Switchgrass seedling development as affected by seed size," Agronomy Journal, vol. 91, no. 2, pp. 335-338, 1999.

[26] G. Sarath, B. Dien, A. J. Saathoff, K. P. Vogel, R. B. Mitchell, and H. Chen, "Ethanol yields and cell wall properties in divergently bred switchgrass genotypes," Bioresource Technology, vol. 102, no. 20, pp. 9579-9585, 2011.

[27] P. R. Adler, M. A. Sanderson, A. A. Boateng, P. J. Weimer, and H.-J. G. Jung, "Biomass yield and biofuel quality of switchgrass harvested in fall or spring," Agronomy Journal, vol. 98, no. 6, pp. 1518-1525, 2006.

[28] J. Burvall, "Influence of harvest time and soil type on fuel quality in reed canary grass (Phalaris Arundinacea L.)," Biomass \& Bioenergy, vol. 12, no. 3, pp. 149-154, 1997.

[29] S. Clarke, P. Eng, and F. Preto, Biomass Burn Characteristics, OMAFRA, Ontario, Canada, 2013, http://www.omafra.gov.on .ca/english/engineer/facts/11-033.pdf.

[30] B. M. Jenkins, L. L. Baxter, and T. R. Miles Jr., "Combustion properties of biomass," Fuel Processing Technology, vol. 54, no. 1-3, pp. 17-46, 1998.

[31] R. Samson, Switchgrass Production in Ontario: A Management Guide, 2007, http://www.reap-canada.com/lirary/Bioenergy/ 2007\%20SG\%20production\%20guide-FINAL.pdf.

[32] R. Samson, E. Delaquis, and G. MacInnis, Enhancing the Commercial Viability of Switchgrass on Marginal Farmland through Plant Breeding, 2014, http://www.reap-canada.com/online_library/feedstock_biomass/Report\%20-\%20Switchgrass\% 20breeding\%20on\%20marginal\%20farmland\%20-\%20Samson, \%20Delaquis,\%20MacInnis\%202013.pdf.

[33] G. W. Burton, "Recurrent restricted phenotypic selection increases forage yields of Pensacola Bahiagrass," Crop Science, vol. 14, no. 6, pp. 831-835, 1974.

[34] K. J. Moore, L. E. Moser, K. P. Vogel, S. S. Waller, B. E. Johnson, and J. F. Pedersen, "Describing and quantifying growth stages of perennial forage grasses," Agronomy Journal, vol. 83, pp. 10731077, 1991.

[35] Association of Official Analytical Chemists, Official Methods for Analysis, AOAC, Arlington, Va, USA, 15th edition, 1990.

[36] P. J. van Soest, J. B. Robertson, and B. A. Lewis, "Methods for dietary fiber, neutral detergent fiber, and nonstarch polysaccharides in relation to animal nutrition," Journal of Dairy Science, vol. 74, no. 10, pp. 3583-3597, 1991.
[37] SAS, SAS Institute Inc. Cary, North Carolina, USA. 2003.

[38] A. Boe and P. O. Johnson, "Deriving a large-seeded switchgrass population using air-column separation of parent seed," Crop science, vol. 27, pp. 147-148, 1987.

[39] R. Lemus, E. C. Brummer, K. J. Moore, N. E. Molstad, C. L. Burras, and M. F. Barker, "Biomass yield and quality of 20 switchgrass populations in southern Iowa, USA," Biomass and Bioenergy, vol. 23, no. 6, pp. 433-442, 2002.

[40] J. H. Fike, D. J. Parrish, D. D. Wolf et al., "Long-term yield potential of switchgrass-for-biofuel systems," Biomass \& Bioenergy, vol. 30, no. 3, pp. 198-206, 2006.

[41] D. R. West and D. R. Kincer, "Yield of switchgrass as affected by seeding rates and dates," Biomass and Bioenergy, vol. 35, no. 9, pp. 4057-4059, 2011.

[42] A. A. Hopkins, K. P. Vogel, K. J. Moore, K. D. Johnson, and I. T. Carlson, "Genotype effects and genotype by environment interactions for traits of elite switchgrass populations," Crop Science, vol. 35, no. 1, pp. 125-132, 1995.

[43] S. D. Wullschleger, E. B. Davis, M. E. Borsuk, C. A. Gunderson, and L. R. Lynd, "Biomass production in switchgrass across the United States: database description and determinants of yield," Agronomy Journal, vol. 102, no. 4, pp. 1158-1168, 2010.

[44] R. Jannasch, P. Duxbury, and R. Samson, Development of bioenergy feedstocks: agronomy data from Eastern Canada, 2001, http://www.reap-canada.com/online_library/feedstock biomass/8-Development $\% 20$ of $\% 20$ Bioenergy\%20Feedstocks-Agronomy\%20Data \%20from \% 20Eastern \%20Canada-Jannasch\% 20et\%20al\%202001.pdf.

[45] D. S. Zamora, G. J. Wyatt, K. G. Apostol, and U. Tschirner, "Biomass yield, energy values, and chemical composition of hybrid poplars in short rotation woody crop production and native perennial grasses in Minnesota, USA," Biomass \& Bioenergy, vol. 49, pp. 222-230, 2013.

[46] M. D. Casler, K. P. Vogel, C. M. Taliaferro, and R. L. Wynia, "Latitudinal adaptation of switchgrass populations," Crop Science, vol. 44, no. 1, pp. 293-303, 2004.

[47] I. C. Madakadze, B. E. Coulman, A. R. Mcelroy, K. A. Stewart, and D. L. Smith, "Evaluation of selected warm-season grasses for biomass production in areas with a short growing season," Bioresource Technology, vol. 65, no. 1-2, pp. 1-12, 1998.

[48] D. D. Redfearn, K. J. Moore, K. P. Vogel, S. S. Waller, and R. B. Mitchell, "Canopy architecture and morphology of switchgrass populations differing in forage yield," Agronomy Journal, vol. 89, no. 2, pp. 262-269, 1997.

[49] D. M. Gustafson, A. Boe, and Y. Jin, "Genetic variation for Puccinia emaculata infection in switchgrass," Crop Science, vol. 43, no. 3, pp. 755-759, 2003.

[50] C. K. Ong, C. Marshall, and G. R. Saoar, "The physiology of tiller death in grasses. 2. Causes of tiller death in a grass sward," Journal of the British Grassland Society, vol. 33, pp. 205-211, 1978.

[51] R. B. Mitchell, L. E. Moser, K. J. Moore, and D. D. Redfearn, "Tiller demographics and leaf area index of four perennial pasture grasses," Agronomy Journal, vol. 90, no. 1, pp. 47-53, 1998.

[52] I. C. Madakadze, B. E. Coulman, P. Peterson, K. A. Stewart, R. Samson, and D. L. Smith, "Leaf area development, light interception, and yield among switchgrass populations in a short-season area," Crop Science, vol. 38, no. 3, pp. 827-834, 1998.

[53] I. Madakadze, B. E. Coulman, K. Stewart, P. Peterson, R. Samson, and D. L. Smith, "Phenology and tiller characteristics of big 
bluestem and switchgrass cultivars in a short growing season area," Agronomy Journal, vol. 90, no. 4, pp. 489-495, 1998.

[54] A. Boe, "Variation between two switchgrass cultivars for components of vegetative and seed biomass," Crop Science, vol. 47, no. 2, pp. 636-642, 2007.

[55] R. Samson, C. Ho Lem, and S. Bailey-Stamler, "Optomization of switchgrass management for commercial fuel pellet production," 2008, http://www.reap-canada.com/online_library/ feedstock_biomass/Optimization \%20of\%20switchgrass \%20management $\% 20$ for $\% 20$ commercial\%20fuel\%20pellet $\% 20$ production\%20(Samson\%20et\%20al.,\%202007).pdf.

[56] A. Prochnow, M. Heiermann, M. Plöchl, T. Amon, and P. J. Hobbs, "Bioenergy from permanent grassland-a review: 2. Combustion," Bioresource Technology, vol. 100, no. 21, pp. 49454954, 2009.

[57] J. Vogel, "Unique aspects of the grass cell wall," Current Opinion in Plant Biology, vol. 11, no. 3, pp. 301-307, 2008.

[58] Z. Hu, R. Sykes, M. F. Davis, E. C. Brummer, and A. J. Ragauskas, "Chemical profiles of switchgrass," Bioresource Technology, vol. 101, no. 9, pp. 3253-3257, 2010.

[59] S. Q. Turn, C. M. Kinoshita, and D. M. Ishimura, "Removal of inorganic constituents of biomass feedstocks by mechanical dewatering and leaching," Biomass \& Bioenergy, vol. 12, no. 4, pp. 241-252, 1997. 


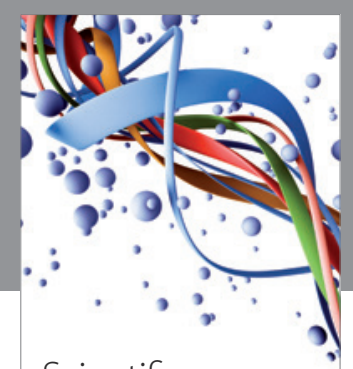

Scientifica
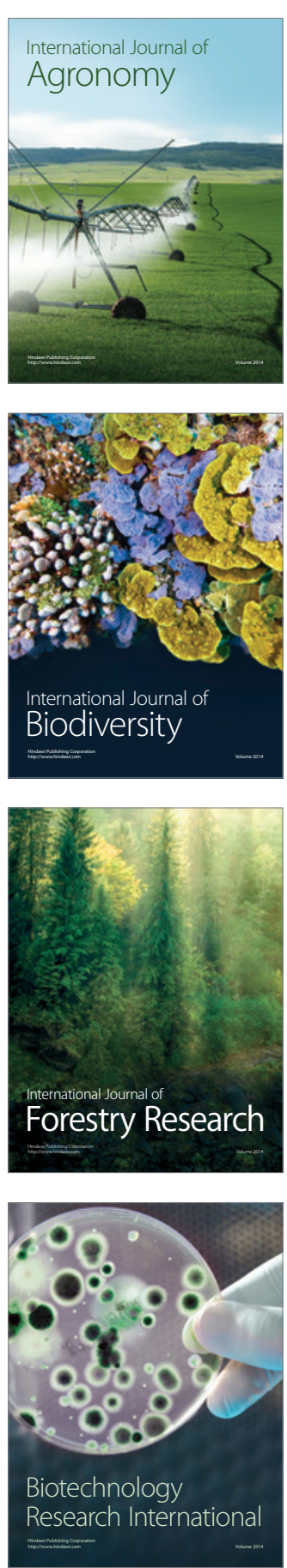
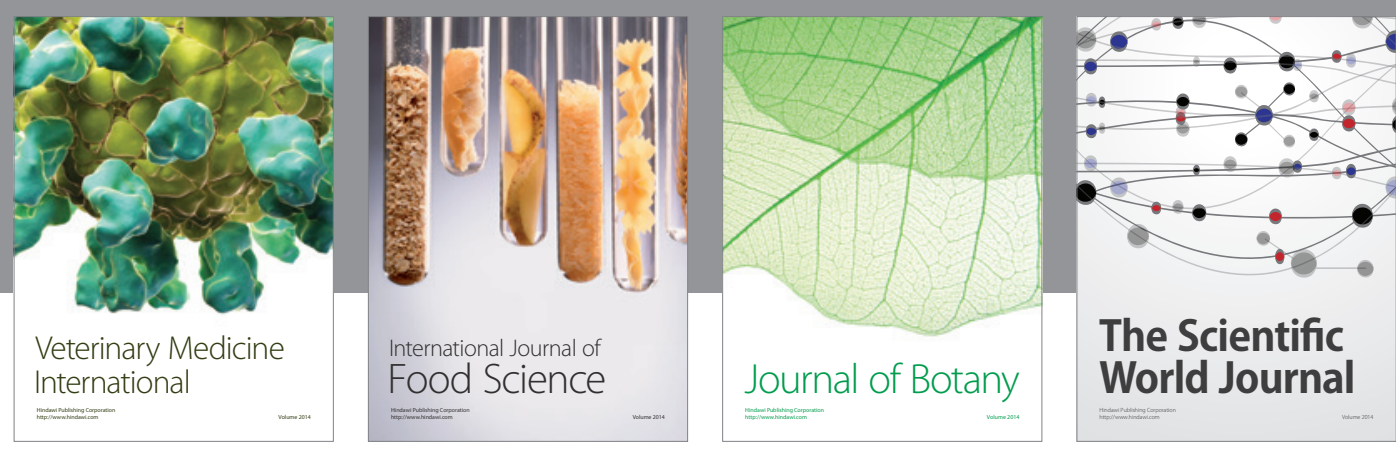

The Scientific World Journal
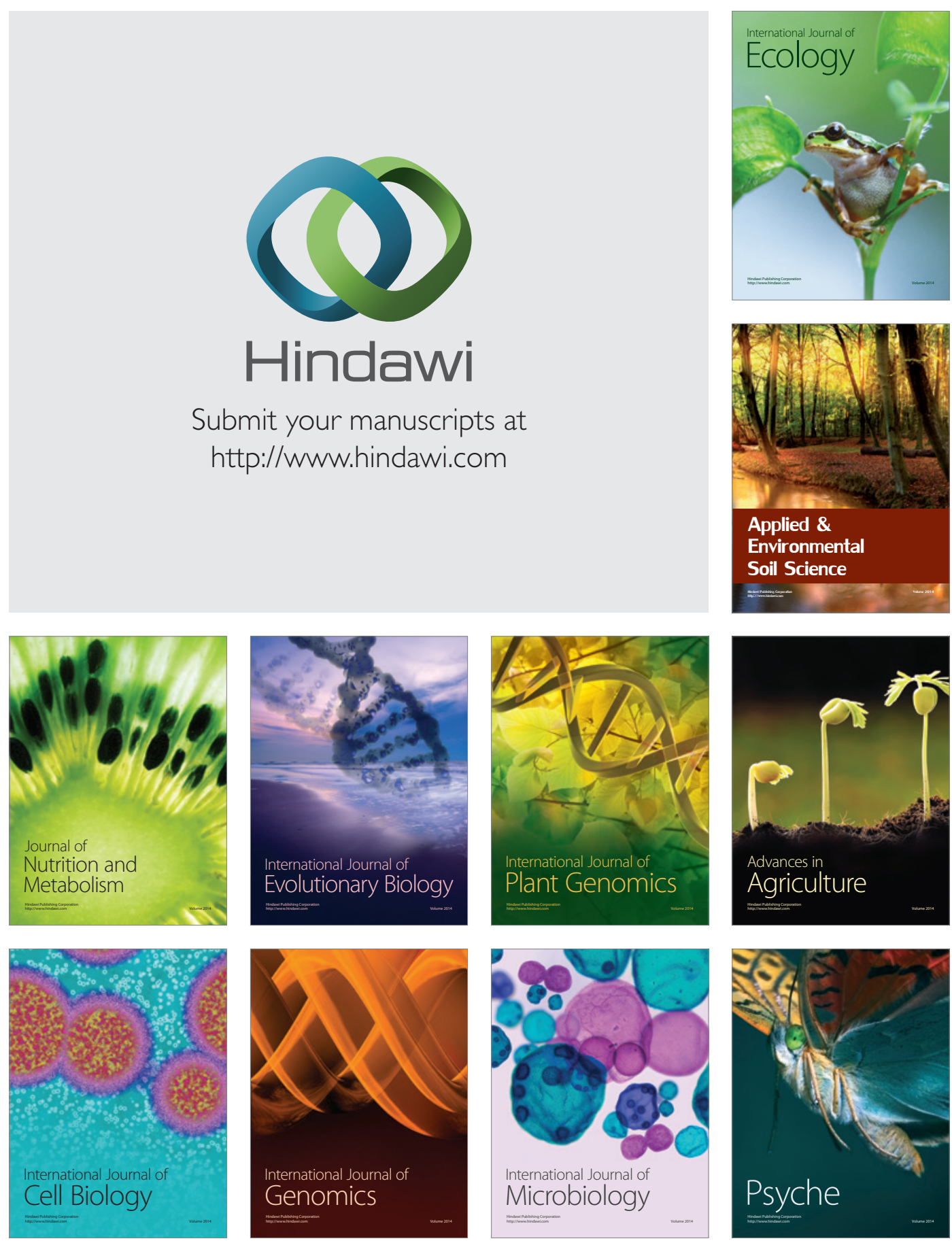